A1-Amwal: Journal of Islamic Economic Law

April 2018, Vol. 3, No. 1

http//www.iainpalopo.ac.id/index.php/alamwal

\title{
KEDUDUKAN BANK SEBAGAI KREDITOR SEPARATIS DALAM PENGURUSAN DAN PEMBERESAN HARTA PAILIT
}

\author{
Yane Pakel \\ Magister Hukum Bisnis, Universitas Gadjah Mada \\ Email : pakelyane@gmail.con
}

\begin{abstract}
There are two purpose of this research 1) to know and analyze bank's role as secured creditor in executing collaterals. This is cause by the uncertainty of the execution rights as a result of the inconsistencies of regulations mention to Article 55, Article 56 and Article 59 of The Republic of Indonesia Number 37 of 2004 regarding Bankruptcy and Suspension of Payment Obligation. 2) to know and examine the legal protection for secure banks in bankruptcy settlement. This research is a normative legal research that is supported by interview. Secondary data is taken from primary, secondary and tertiary legal resource. Data collection method is documentary study and library research. Data analysis is a qualitative analysis.

Based on the result and discussion, bank as a secured creditor has the right to execute collateral that is pledged by debtor, as if bankruptcy does not take place (pursuant to Article 55 paragraph 1)The bankruptcy law has ruled the creditor's right on the collateral, but there is uncertainty of execution right. This is caused by the inconsistency of regulations of Article 55, Article 56 and Article 59 of The Republic of Indonesia Number 37 of 2004 regarding Bankruptcy and Suspension of Payment Obligation. Article 56 and Article 59 are limit the creditor's rights. The current law does not strongly enforced, thus the bank is seeking right by auction or hidden transaction.
\end{abstract}

Keywords: Bank, Secured Creditor, Bankruptcy Settlement

\begin{abstract}
Abstrak
Tujuan penelitian ini untuk 1) mengetahui dan menganalisis kedudukan bank sebagai kreditor separatis dalam mengeksekusi barang jaminan karena tidak terdapat kepastian hak eksekusi yang disebabkan inkonsistensi pengaturan dalam Pasal 55, Pasal 56 dan Pasal 59 Undang-Undang No 37 Tahun 2004 tentang Kepailitan dan Penundaan Kewajiban Pembayaran Utang dan 2) mengetahui dan mengkaji perlindungan hukum terhadap bank yang berkedudukan sebagai kreditor separatis dalam pembagian harta pailit. Penelitian ini merupakan penelitian hukum normatif yang didukung dengan wawancara. Data yang digunakan adalah data sekunder yang berasal dari bahan hukum primer, sekunder dan tersier. Cara pengumpulan data yang dilakukan ialah studi dokumen dan penelitian kepustakaan dilakukan dengan cara studi dokumentasi. Analisis data yang digunakan ialah analisis kualitatif. Berdasarkan hasil penelitian dan pembahasan menunjukkan bahwa bank dalam hal ini berkedudukan sebagai kreditor separatis dan mempunyai hak eksekusi atas barang jaminan yang dijaminkan oleh debitor seolah-olah tidak terjadi kepailitan
\end{abstract}


berdasarkan Pasal 55 ayat (1). Kedudukan kreditor separatis tidak terdapat kepastian hak eksekusi yang disebabkan inkonsistensi pengaturan dalam Pasal 55, Pasal 56 dan Pasal 59 Undang-Undang No 37 Tahun 2004 tentang Kepailitan dan Penundaan kewajiban Pembayaran Utang. Pasal 56 dan Pasal 59 secara tidak langsung memberikan adanya batasan-batasan terhadap kreditor separatis untuk memperoleh haknya. Perlindungan yang diberikan oleh hukum terhadap kreditor separatis telah diatur akan tetapi tidak konsisten sehingga bank harus berupaya untuk mendapatkan haknya.

Kata Kunci : Bank, Kreditor Separatis, Harta Pailit

\section{PENDAHULUAN}

Krisis moneter pada tahun 1997 di Indonesia membuat utang menjadi membengkak luar biasa sehingga mengakibatkan banyak sekali debitor tidak mampu membayar utangutangnya. Hal tersebut juga terjadi di kalangan perbankan yakni kredit macet di ndonesia makin membubung tinggi karena krisis moneter (sebelum krisis moneter perbankan Indonesia memang juga telah menghadapi masalah kredit bermasalah atau non-performing loans yang memprihatinkan).

Lembaga perbankan merupakan inti dari sistem keuangan dari setiap negara. Di Indonesia sistem keuangan dapat dikelompokkan menjadi dua, yaitu sistem moneter dan lembaga keuangan lainnya. ${ }^{1}$ Sistem moneter yang dimaksudkan pada lembaga perbankan ialah penanggung jawab otoritas kebijakan menter terletak pada Bank Indonesia yang berwenang untuk menetapkan dan melaksanakan kebijakan moenter dalam rangka mencapai serta memelihara kestablian nilai rupiah, sedangkan lembaga keuangan lainnya ialah semua badan yang melakukan kegiatan di bidang keuangan secara langsung atau secara tidak langsung dalam menghimpun dana terutama dengan jalan mengeluarkan kerta berharga dan menyalurkannya pada masyarakat terutama guna membiayai investasi perusahanperusahan. ${ }^{2}$ Adapun contoh-contoh lembaga keuangan bukan bank diantaranya yakni pegadaian, asuransi, dan koperasi. Krisis moneter yang terjadi memberikan dampak yang cukup signifikan terhadap perkembangan perekonomian Negara Indonesia pada saat itu.

\footnotetext{
${ }^{1}$ Insukrindo, "Ekonomi Uang dan Bank", dalam Hermasyah, 2008, Hukum Perbankan Nasional Indonesia, Prenada Media Group, Jakarta, hlm. 2

${ }^{2}$ Ibid, hlm. 2
} 
Adanya kecenderungan dunia usaha menjadi tidak berkembang bahkan mengalami pailit yang berakibat tidak dapat memenuhi kewajiban-kewajiban yang sudah jatuh tempo. Pemerintah melakukan perubahan-perubahan yang cukup signifikan dalam peraturan perundang-undangan salah satunya adalah merevisi peraturan kepailitan (Faillisement Verordening). Inisiatif pemerintah untuk merevisi Faillisement Verordening sebenarnya timbul karena ada tekanan dari Dana Moneter Internasional/International Monetary Fund (IMF) yang mendesak supaya Indonesia menyempurnakan sarana hukum yang mengatur permasalahan pemenuhan kewajiban oleh debitor kepada kreditor. ${ }^{3}$

IMF berpendapat bahwa upaya untuk mengatasi krisis monter di Indonesia tidak dapat terlepas dari keharusan penyelesaian utang luar negeri dan upaya penyelesaian kreditkredit macet perbankan Indonesia. IMF mendesak pemerintah agar segera mengganti atau mengubah peraturan kepailitan yang berlaku. Akibat desakan tersebut, lahirlah Perpu No. 1 Tahun 1998 tentang Perubahan Atas Undang-Undang Tentang Perpu Kepailitan. Perpu tersebut mengubah dan menambah Peraturan Kepailitan (Faillissementsverordening). ${ }^{4}$ Perpu Kepailitan bukan sesuatu yang bersifat darurat. Ketentuan-ketentuan Perpu Kepailitan adalah sesuatu yang bersifat normal yang berlaku dan dijalankan terus dikemudian hari. Perpu Kepailitan ditetapkan karena keterdesakan waktu didorong oleh kebutuhan mendesak sebagai bagian dari upaya mengatasi krisis moneter dan ekonomi yang terjadi. ${ }^{5}$

Pailit merupakan suatu keadaan dimana debitor tidak mampu untuk melakukan pembayaran-pembayaran terhadap utang-utang dari para kreditornya. ${ }^{6}$ Keadaan tidak mampu membayar lazimnya disebabkan karena kesulitan keuangan dari usaha debitor yang telah mengalami kemuduran. Penyelesaian utang-piutang antara debitor dengan kreditor

\footnotetext{
${ }^{3}$ Ahmad Yani dan Gunawan Widjaja, 2004, Seri Hukum Bisnis Kepailitan, PT. RajaGrafindo Persada, Jakarta, hlm.1

${ }^{4}$ Adrian Sutedi, 2009, Hukum Kepailitan, Ghalia Indonesia, Bogor, hlm. 5

5 Bagir Manan "Mengenal PERPU Kepailitan” dalam Rudhy A. Lontoh, dkk., 2001, Mengenal Perpu Kepailitan, Penyelesaian Utang-Piutang, Melalui Pailit atau Penundaan Kewajiban Pembayaran Utang, Alumni, Bandung, hlm. 67

${ }^{6}$ M. Hadi Shubban, 2008, Hukum Kepailitan Prinsip, Norma, dan praktik di Peradilan, Kencana Prenadamedia Group, Jakarta, hlm. 1
} 
melalui lembaga kepailitan dapat dilakukan sebagai salah satu alternatif penyelesaian utang-piutang. Lembaga kepailitan yang dimaksudkan ialah Pengadilan Niaga (Commercial Court) dimana bertugas dalam hal menangani permohonan pernyataan pailit dan penundaan kewajiban pembayaran utang. Kepailitan yang dimaksudkan bertujuan untuk menghindari terjadinya sitaan yang dilakukan secara terpisah atau eksekusi terpisah oleh kreditor dan menggantikannya dengan mengadakan sitaan bersama sehingga kekayaan debitor dapat dibagikan kepada semua kreditor sesuai dengan hak masing-masing.

Hal ini termuat dalam Pasal 1131 KUH Perdata yang menyatakan bahwa segala kebendaan debitor ${ }^{7}$, baik yang bergerak maupun tidak bergerak, baik yang sudah ada maupun yang baru akan ada di kemudian hari, menjadi tanggungan untuk segala perikatannya perseorangan. Kesimpulan dari Pasal 1131 KUH Perdata ialah setiap tindakan yang dilakukan seseorang dalam lapangan harta kekayaan selalu akan membawa akibat terhadap harta kekayaannya, baik yang bersifat menambah jumlah harta kekayaannya (kredit), maupun yang nantinya akan mengurangi jumlah harta kekayaannya (debit). Demikianlah harta kekayaan setiap orang akan selalu berada dalam keadaan yang dinamis dan selalu berubah-ubah dari waktu ke waktu. Setiap perjanjian dibuat maupun perikatan yang terjadi dapat mengakibatkan harta kekayaan seseorang bertambah atau berkurang. ${ }^{8}$ Pasal 1132 KUH Perdata menyebutkan bahwa kebendaan tersebut menjadi jaminan bersama-sama bagi semua orang yang mengutangkan padanya, pendapatan penjualan benda-benda itu dibagi-bagi menurut keseimbangannya itu menurut besar kecilnya piutang masing-masing, kecuali apabila di antara para kreditor ${ }^{9}$ itu ada alasan-alasan yang sah untuk didahulukan.

Konstruksi hukum berdasarkan kedua Pasal diatas mempunyai persamaan dengan kredit yang diberikan bank apabila debitor dipailitkan dan kreditor tidak mempunyai hak preferen, maka asas-asas yang diatur dalam Pasal 1131 dan 1132 KUH Perdata tersebut berlaku juga dalam pemberian kredit.

\footnotetext{
${ }^{7}$ Dalam istilah di Pasal 1131 KUH Perdata, debitor diistilahkan sebagai si berutang

${ }^{8}$ Kartini Mulyadi, 2005, Kreditor Preferen dan Kreditor Separatis dalam Kepailitan, Pusat Pengkajian Hukum, Jakarta, hlm. 164

${ }^{9}$ Dalam istilah di Pasal 1132 KUH Perdata, kreditor diistilahkan sebagai berpiutang
} 
Berdasarkan pemaparan diatas, berdasarkan Pasal 1 angka 2 Undang-Undang Nomor 37 tahun 2004 tentang Kepailitan dan Penundaan Kewajiban Pembayaran Utang menyebutkan bahwa kreditor adalah orang yang mempunyai piutang karena perjanjian atau undang-undang yang dapat ditagih di muka pengadilan. Dalam hal ini bank dapat berkedudukan sebagai seorang kreditor yang bertujuan untuk memberikan pinjaman berupa dana kepada orang yang membutuhkan sesuai dengan pengertian bank berdasarkan Pasal 1 angka 2 Undang-Undang Nomor 10 Tahun 1998 tentang Perbankan yang menyebutkan bahwa bank adalah badan usaha yang menghimpun dana dari masyrakat dalam bentuk simpanan dan menyalurkannya kepada masyarakat dalam bentuk kredit dan atau bentukbentuk lainnya dalam rangka meningkatkan taraf hidup rakyat banyak.

Dalam hal peminjaman kredit diperuntukkan untuk kelangsungan hidup masyrakat sebagai debitor untuk mendapatkan jaminan hidup yang lebih baik. Proses untuk peminjaman kredit diikat oleh adanya persetujuan antara kedua belah pihak yakni kreditor dan debitor yang bertujuan agar para pihak yang terlibat dalam peminjaman kredit dapat melaksanakan hak dan kewajibannya dalam jangka waktu yang telah disepakati bersama. Peminjaman kredit juga memerlukan adanya jaminan yang akan diberikan dari pihak debitor kepada kreditor dengan tujuan apabila suatu saat debitor tidak mampu membayar utang-utangnya maka kreditor memiliki kewenangan untuk mengeksekusi jaminan tersebut untuk melunasi utang.

Berkaitan dengan penjelasan diatas, seringkali hubungan antara kreditor dan debitor tidak berjalan dengan baik apabila debitor tidak mampu membayar atau melunasi utangutangnya terhadap kreditor. Maka, terjadi sengketa antara kedua belah pihak akan tetapi banyak cara untuk menyelesaikan sengketa tersebut salah satunya ialah kepailitan.

Kreditor dapat berupa kreditor konkuren ${ }^{10}$, kreditor preferen ${ }^{11}$ dan kreditor separatis. Kreditor separatis adalah kreditor yang memiliki jaminan utang kebendaan (hak jaminan)

\footnotetext{
${ }^{10}$ Kreditor konkuren adalah kreditor yang mempunyai hak pari passu prorate parte, para kreditor yang mendapatkan pelunasan secara bersama-sama tanpa hak yang didahulukan, dihitung besarnya piutang masing-masing terhadap piutang secara keseluruhan dari seluruh kekayaan debitor. Lilik Mulyadi, 2013, Perkara Kepailitan Penundaan Kewajiban Pembayaran Utang (PKPU) Teori dan Praktek, PT. Alumni, Bandung, hlm. 98
} 
seperti pemegang hak tanggungan, hipotek, gadai, fidusia dan lain-lain (Pasal 56 UndangUndang Kepailitan). ${ }^{12}$ Separatis berkonotasi pemisahan karena kedudukan kreditor tersebut memang dipisahkan dari kreditor lainnya, dalam arti dia dapat menjual dan mengambil sendiri dari hasil penjualan yang terpisah dengan harta pailit umum lainnya. ${ }^{13}$

Ketentuan yang mengatur mengenai hak kreditor separatis ialah Pasal 55, Pasal 56 dan Pasal 59 Undang-Undang Nomor 37 Tahun 2004 tentang Kepailitan dan Penundaan Kewajiban Pembayaran Utang, namun ketiga Pasal yang telah disebutkan dalam ayat-ayat tertentu terdapat tidak konsistennya dalam memberikan kepastian terhadap hak kreditor separatis. Pasal 55 ayat (1) menyebutkan bahwa dengan tetap memperhatikan ketentuan sebagaimana dimaksud dalam Pasal 56, Pasal 57, dan Pasal 58, setiap kreditor pemegang gadai, jaminan fidusia, hak tanggungan, hipotek, atau hak agunan atas kebendaan lainnya, dapat mengeksekusi haknya seolah-seolah tidak terjadi kepailitan. Pasal 55 ayat (1) tidak dapat dilaksanakan sesuai dengan ketentuan yang diatur dikarenakan Pasal tersebut tidak konsisten dengan Pasal 56 ayat (1) yang menyebutkan bahwa hak eksekusi kreditor sebagaimana dimaksud dalam Pasal 55 ayat (1) dan hak pihak ketiga untuk menuntut hartanya yang berada dalam penguasaan debitor pailit atau kurator, ditangguhkan untuk jangka waktu paling lama 90 hari sejak tanggal putusan pernyataan pailit diucapkan. Berdasarkan Pasal 55 ayat (1) hak kreditor separatis dapat mengeksekusi haknya seolaholah tidak terjadi kepailitan, akan tetapi Pasal 56 ayat (1) adanya pembatasan terhadap jangka waktu yang diberikan kepada kreditor separatis untuk menuntut hartanya dengan jangka waktu paling lama 90 hari, sehingga kedua pasal tersebut tidak memberikan adanya kepastian terhadap kreditor separatis untuk menuntut haknya dan tidak terdapat konsistensi terhadap kedua Pasal tersebut. Ketentuan yang tidak konsisten mengatur mengenai kepastian terhadap kedudukan hak kreditor separatis juga terdapat pada Pasal 59 ayat (1) yang menyebutkan bahwa dengan tetap memperhatikan ketentuan Pasal 56, Pasal 57, dan

\footnotetext{
${ }^{11}$ Kreditor preferen mempunyai piutang-piutang yang berkedudukan istimewa atau privilege sebagaimana ketentuan Pasal 1139 dan 1149 KUHPerdata.Ibid, hlm. 96

${ }^{12}$ Munir Fuady, 2005, Hukum Pailit Dalam Teori dan Praktek, PT. Citra Aditya Bakti, Bandung, hlm. 99

${ }^{13}$ Ibid, hlm. 99
} 
Pasal 58, kreditor pemegang hak sebagaimana dimaksud dalam Pasal 55 ayat (1) harus melaksanakan haknya tersebut dalam jangka waktu paling lambat dua bulan setelah dimulainya keadaan insolven sebagaiman dimaksud dalam Pasal 178 ayat (1). Pasal 59 ayat (1) juga tidak konsisten dengan ketentuan yang ditetapkan dalam Pasal 55 ayat (1) yang secara tegas menyebutkan mengenai hak eksekusi seolah-olah tidak terjadi kepailitan. Berdasarkan uraian singkat dari latar belakang masalah penelitian yang diuraikan sebelumnya maka penelitian ini dilakukan. Bagaimana kedudukan bank sebagai kreditor separatis dalam mengeksekusi barang jaminan karena tidak terdapat kepastian hak eksekusi yang disebabkan inkonsistensi pengaturan dalam Pasal 55, Pasal 56 dan Pasal 59 UndangUndang No 37 Tahun 2004 tentang Kepailitan dan Penundaan Kewajiban Pembayaran Utang? Bagaimana perlindungan hukum terhadap bank yang berkedudukan sebagai kreditor separatis apabila tidak mendapatkan haknya dalam pembagian harta pailit?

\section{METODE PENELITIAN}

Sifat Penelitian yang digunakan adalah hukum normatif yang didukung dengan wawancara dan jenis penelitian yang digunakan adalah kepustakaan. Penelitian hukum normatif adalah metode yang menguji kualitas dari suatu norma hukum yang berkaitan dengan isu hukum yang terjadi berdasarkan pada pembenaran dari undang-undang, pendapat para ahli hukum dan buku-buku mengenai teks hukum. ${ }^{14}$ Bahan penelitian terbagi atas tiga yakni bahan hukum primer, bahan hukum sekunder dan bahan hukum tersier. Ketiga bahan penelitian tersebut merupakan bagian dari data sekunder yang diperoleh dari studi pustaka.Cara pengumpulan data yang dilakukan dalam penelitian ini ialah studi dokumen. Penelitian kepustakaan ini dilakukan dengan carastudi dokumentasi yaitu dengan cara mempelajari bahan-bahan hukum baik yang merupakan bahan hukum primer, bahan hukum sekunder dan bahan hukum tersier yang berkaitan dengan penelitian. Analisis data dalam penelitian ini menggunakan analisis kualitatif, setelah data dianalisis dan dibahas, kemudian ditarik kesimpulan dengan metode deduktif.

\footnotetext{
${ }^{14}$ Peter Mahmud Marzuki, 2005, Penelitian Hukum, Prenada Media Group, Jakarta, hlm. 35
} 


\section{KEDUDUKAN BANK SEBAGAI KREDITOR SEPARATIS DALAM MENGEKSEKUSI BARANG JAMINAN}

Makna dari kata separatis ialah pemisahan. Kedudukan kreditor separatis dipisahkan dari kreditor lainnya. Kreditor separatis merupakan pemegang jaminan utang kebendaan seperti pemegang hak tanggungan, hipotik, gadai, fidusia dan hak agunan atas kebendaan lainnya yang telah disebutkan berdasarkan Pasal 55 ayat (1) Undang-Undang Nomor 37 Tahun 2004 tentang Kepailitan dan Penundaan Kewajiban Pembayaran Utang. Separatis diartikan bahwa dalam hal adanya kepailitan ada penagih yang berhak mendahului piutangnya. ${ }^{15}$ Separatis dalam kepailitan dapat diartikan bahwa seorang yang berada di luar kepailitan dan juga tidak turut memikul ongkos-ongkos. Kreditor Separatis ${ }^{16}$ melaksanakan haknya seakan-akan tidak ada kepailitan. ${ }^{17}$

\section{a. Kedudukan Kreditor Separatis Dalam Kepailitan}

Tujuan dari kepailitan ialah melakukan pembagian harta pailit milik debitor kepada para kreditor dan pembagiannya pun sesuai dengan proporsi masing-masing kreditor. Berkaitan dengan asas paritas creditorium dan asas pari passu pro rata parte, maka kedua asas tersebut juga berkaitan dengan pelaksanaan dari Pasal 1131 dan 1132 KUHPerdata. Pasal 1131 KUHPerdata yang menentukan bahwa seluruh harta benda milik debitor baik benda yang bergerak maupun yang tidak bergerak menjadi jaminan bagi seluruh perikatannya dan pasal tersebut berkaitan dengan asas paritas creditorium, sedangkan Pasal 1132 KUHPerdata yang pada intinya menentukan bahwa harta kekayaan milik debitor merupakan jaminan bersama para kreditor dan hasilnya harus dibagikan secara proporsional, yang merupakan penjabaran dari asas pari passu pro rata parte. ${ }^{18}$

Penjelasan Pasal 56 ayat (1) Undang-Undang Nomor 37 Tahun 2004 tentang Kepailitan dan Penundaan Kewajiban Pembayaran Utang menyebutkan mengenai tujuan dari penangguhan ialah:

\footnotetext{
${ }^{15}$ Yan Pramadya Puspa, 1977, Kamus Hukum Edisi Lengkap Bahasa Belanda Indonesia, Inggris, Aneka Ilmu, Semarang, hlm. 767

${ }_{16}$ Lihat dalam Andi Hamzah, 1986, Kamus Hukum, Ghalia Indonesia, Jakarta, hlm. 535

${ }^{17}$ Andi Hamzah, 1986, Kamus Hukum, Ghalia Indonesia, Jakarta, hlm. 535

${ }^{18}$ Ibid, hlm. 101
} 
1) Memperbesar kemungkinan tercapainya perdamaian; atau

2) Memperbesar kemungkinan mengoptimalkan harta pailit; atau

3) Memungkinkan kurator melaksanakan tugasnya

Penjelasan pada Pasal 56 ayat (1) juga menambahkan bahwa saat berlangsung jangka waktu penangguhan, segala tuntutan hukum untuk memperoleh pelunasan atas suatu piutang tidak dapat diajukan dalam sidang badan peradilan, dan baik kreditor maupun pihak ketiga dimaksud dilarang mengeksekusi atau memohonkan sita atas benda menjadi agunan.

Tujuan masa penangguhan pertama, tidak sesuai dengan salah satu syarat pailit yakni tidak membayar lunas sedikitnya satu utang yang telah jatuh waktu dan dapat ditagih merujuk pada Pasal 2 ayat (1) Undang-Undang Nomor 37 Tahun 2004 tentang Kepailitan dan Penundaan Kewajiban Pembayaran utang. Tujuan dari masa penangguhan ialah untuk mencapai perdamaian maka hal ini tidak memenuhi syarat pailit. Hal ini dikarenakan bahwa seorang kreditor memiliki hak dan kewenangan untuk menagih harta kekayaan milik debitor apabila utang yang dimiliki oleh debitor telah jatuh tempo. Kedudukan kreditor separatis seperti yang dijelaskan sebelumnya merupakan kreditor yang terpisah dari kreditor-kreditor lainnya dalam hal mengeksekusi barang jaminan milik debitor. Permasalahan perdamaian yang ingin dicapai dari tujuan masa penangguhan tidak sejalan dengan kedudukan kreditor separatis pada Pasal 55 ayat (1) Undang-Undang Nomor 37 Tahun 2004 tentang Kepailitan dan Penundaan Kewajiban Pembayaran Utang. Tujuan perdamaian yang ingin dicapai apabila dilaksanakan, maka hak eksekusi kreditor separatis tidak ada artinya. Disisi lain, apabila eksekusi kreditor separatis dilaksanakan, maka tujuan perdamaian tidak dapat dicapai. Hasil wawancara dengan kepala bagian divisi legal Bank $\mathrm{Z}^{19}$ untuk menanggapi tujuan masa penangguhan yang pertama tentang perdamaian, dalam hal ini Bank $\mathrm{Z}$ tidak menyetujuinya dikarenakan bahwa Bank $\mathrm{Z}$ sangat memprioritaskan pelunasan utang yang harus dilakukan oleh debitor. ${ }^{20}$

\footnotetext{
${ }^{19}$ Demi menjaga kerahasiaan, maka narasumber tidak menginginkan nama instansinya dicantumkan

${ }^{20}$ Anonim, 2016, Kedudukan Kreditor Separatis Dalam Mengeksekusi Barang Jaminan , Wawancara, 29 Agustus
} 
Kepala divisi legal Bank $\mathrm{Z}$ mengungkapkan bahwa apabila debitor cidera janji dalam hal tidak dapat melakukan pembayaran kepada kreditor sesuai dengan kesepakatan kedua belah pihak, maka kreditor akan melaksanakan haknya untuk menjual barang jaminan milik debitor agar dapat menutupi atau melunasi utangnya. Pada saat melakukan penjualan akan tetapi hasilnya tidak mencukupi atau tidak dapat melunasi utangnya maka kreditor akan tetap menutunt sisa utang yang belum dilunasi hingga utang hingga debitor melunasi utangutangnya sesuai dengan perjanjian kredit yang telah dibuat dan disetujui oleh kreditor dan debitor. Kepala bagian divisi legal Bank Z juga menambahkan bahwa sisa utang yang belum dilunasi oleh debitor akan dicatat dalam hapus buku atau right off dan juga akan dimasukkan ke rekening extracomptable, sehingga menunjukkan bahwa debitor masih memiliki utang yang wajib dibayarkan kepada bank. Hal lain yang juga dilakukan oleh kreditor dalam hal ini bank untuk memperjuangkan hak atas piutangnya, kepala divisi legal Bank Z mengungkapkan bahwa apabila debitor belum melunasi utangnya, maka nama debitor akan juga dicantumkan dalam daftar nama kredit macet di Bank Indonesia dan akan disebarkan di seluruh bank di Indonesia. Tujuan dari hal tersebut dilakukan agar debitor yang belum melunasi utangnya tidak akan mendapatkan fasilitas kredit dari Bank Z maupun bank-bank lainnya, selain itu juga hal tersebut dapat memberikan dorongan untuk debitor untuk melunasi utangnya ${ }^{21}$

\section{b. Kewenangan Kreditor Separatis Dalam Eksekusi Barang Jaminan}

Kreditor diberikan hak secara khusus untuk menjual barang jaminan milik debitor apabila debitor cidera jani dan pelaksanaan hak tersebut dikenal dengan nama parate executie. Parate executie atau eksekusi langsung merupakan hak kreditor pertama untuk menjual barang-barang tertentu milik debitor secara lelang tanpa terlebih dahulu mendapatkan putusan pengadilan. Pengaturan parate executie diatur secara khusus peraturan jaminan kebendaan yakni gadai diatur dalam Pasal 1155 KUHPerdata, hipotek,

\footnotetext{
${ }^{21}$ Anonim, 2016, Kedudukan Kreditor Separatis Dalam Mengeksekusi Barang Jaminan, Wawancara, 29 Agustus
} 
hak tanggungan diatur dalam Pasal 6 UUHT, jaminan fidusia diatur dalam Pasal 29 ayat (1) huruf $b .^{22}$

Lelang merupakan langkah awal yang harus dilaksanakan sebelum dilakukannya pengalihan secara bawah tangan. Pasal 185 ayat (1) Undang-Undang No 37 Tahun 2004 tentang Kepailitan dan Penundaan Kewajiban Pembayaran Utang menyebutkan bahwa semua benda harus dijual di muka umum sesuai dengan tata cara yang ditentukan dalam peraturan perundang-undangan, dan ayat (2) menyebutkan bahwa dalam hal penjualan di muka umum sebagaimana dimaksud pada ayat (1) tidak tercapai, maka penjualan di bawah tangan dapat dilakukan dengan izin hakim pengawas. Berdasarkan Pasal 185 ayat (1) dan ayat (2) dapat dilihat bahwa ada dua cara kreditor melakukan eksekusi terhadap objek jaminan kredit yakni melalui kantor lelang dan penjualan dibawah tangan.

Berdasarkan hasil wawancara dengan kepala bagian divisi legal Bank $\mathrm{X}^{23}$ belum pernah mengalami kredit macet yang salah satu penyebabnya ialah debitor pailit, sehingga berkaitan dengan eksekusi terhadap barang jaminan juga belum pernah dilakukan oleh Bank X, akan tetapi apabila hal itu akan terjadi dikemudian hari maka yang akan ditempuh ialah: ${ }^{24}$

a) Permintaan pertanggung jawab dari debitor untuk membayar utang

b) Apabila debitor tidak mampu membayar utang, maka bank akan mengeksekusi barang jaminan milik debitor guna untuk menutupi utang

c) Eksekusi barang jaminan tersebut, maka yang akan dilakukan ialah melalui lelang guna untuk mendapatkan peminat terhadap barang jaminan tersebut setelah itu uang yang telah didapatkan dari hasil lelang akan digunakan untuk menutupi utang debitor.

\footnotetext{
${ }^{22}$ Ivida Dewi Amrih Suci, op.cit, hlm. 138

23 Demi menjaga kerahasiaan, maka narasumber tidak menginginkan nama instansinya dicantumkan

${ }^{24}$ Anonim, 2016, Kedudukan Kreditor Separatis Dalam Mengeksekusi Barang Jaminan, Wawancara, 29 Agustus
} 
Bank $\mathrm{X}^{25}$ menyatakan bahwa belum pernah mengalami adanya debitor pailit, hal serupa juga belum pernah dialami pada Bank Y dan Bank Z. Kepala bagian divisi legal Bank Z mengungkapkan bahwa meskipun belum pernah mengalami adanya debitor yang pailit, namun dalam hal debitor tidak mampu membayar utang-utangnya maka yang akan dilakukan dua cara untuk mengeksekusi barang jaminan diantaranya ialah lelang dan penjualan di bawah tangan. Bank $\mathrm{Z}$ akan melakukan lelang terhadap barang jaminan yang diberikan oleh debitor atau juga melalui kantor lelang, namun Bank Z lebih memilih untuk mengeksekusi barang jaminan melalui lelang secara langsung. Cara yang kedua ialah penjualan di bawah tangan, yang akan dilakukan pada cara ini yakni debitor akan menemukan pembeli untuk membeli barang jaminan, kemudian hasilnya akan diserahkan kepada kreditor dalam hal ini bank yang berkedudukan sebagai kreditor. Lelang dan penjualan di bawah tangan akan dilaksanakan apabila terjadinya kredit macet. Terdapat lima tahapan kredit atau kualitas kredit yang sesuai dengan ketentuan Bank Indonesia yakni kredit lancar, kredit dalam perhatian khusus, kredit kurang lancar, kredit di ragukan, dan kredit macet. $^{26}$

\section{c. Kedudukan Bank Sebagai Kreditor Separatis Dalam Pemberesan dan}

\section{Pengurusan Harta Pailit}

Bank dalam memberikan kredit kepada nasabah dilakukan dengan pemberian jaminan, jaminan tersebut dapat terdiri atas: ${ }^{27}$

1) Jaminan kebendaan, yang diikat dengan hak tanggungan, hak gadai, fidusia, dan hak agunan lainnya.

2) Jaminan perorangan atau penanggungan/borgtocht yang terdiri dari personal guarantee dan corporate guarantee.

\footnotetext{
${ }^{25}$ Anonim, 2016, Kedudukan Kreditor Separatis Dalam Mengeksekusi Barang Jaminan, Wawancara, 29 Agustus

26 Anonim, 2016, Kedudukan Kreditor Separatis Dalam Mengeksekusi Barang Jaminan , Wawancara, 29 September

${ }^{27}$ Sis Abadi S, "Hukum Kepailitan Ditinjau Dari Aspek Perbankan" dalam Rudhy A. Lontoh, dkk., 2001, Mengenal Perpu Kepailitan, Penyelesaian Utang-Piutang, Melalui Pailit atau Penundaan Kewajiban Pembayaran Utang, Alumni, Bandung, hlm. 419
} 
Pada dasarnya bahwa kreditor separatis adalah kreditor yang pembayaranya dijamin dengan jaminan ${ }^{28}$, maka kreditor separatis mempunyai hak yang telah diberikan oleh hukum untuk mengeksekusi barang jaminan.

Kepailitan terdiri atas dua fase, yakni fase penitipan atau sekestrasi (cocervatoir) dan fase insolvensi atau fase eksekutor. ${ }^{29}$ Berdasarkan dua fase yang disebutkan, maka fase penitipan dikategorikan pada pengurusan harta pailit, sedangkan fase insolvensi merupakan bentuk dari pemberesan harta pailit. Berdasarkan hasil wawancara dengan kepala bagian divisi legal Bank $\mathrm{X}$ bahwasannya dalam hal debitor telah dinyatakan pailit, maka ada beberapa hal yang akan di laksanakan guna untuk mendapatkan haknya dari piutang, yakni $:^{30}$

a) Bank $\mathrm{X}$ wajib hadir dalam rapat verifikasi jumlah utang dengan membawa asli perjanjian kredit dan perhitungan jumlah kewajiban

b) Bank X selaku secured creditor dapat menjalankan eksekusi

c) Perlu dilakukan koordinasi yang baik dengan kurator

d) Legal officer tetap wajib mengetahui setiap agenda pertemuan dengan kreditor

Menitikberatkan pada poin kedua yang disampaikan oleh kepala bagian divisi legal Bank X bahwa secured creditor atau kreditor separatis dapat menjalankan eksekusi, maka hal ini sejalan dengan Pasal 55 ayat (1) Undang-Undang No 37 Tahun 2004 tentang Kepailitan dan Penundaan Kewajiban Pembayaran Utang. Selain itu, berdasarkan hasil wawancara dengan Bank X dapat dinilai bahwa apabila terjadi debitor pailit maka Bank X lebih memilih melaksanakan fase insolvensi disbanding melakasanakan fase penitipan atau sekestrasi. $^{31}$

\footnotetext{
${ }^{28}$ Elijana, “Kedudukan Kreditor Dalam Kepailitan”, dalam Tata Wijayanta, 2016,Undang-Undang dan Praktik Kepailitan, Gadjah Mada University Press, Yogyakarta, hlm. 199

${ }^{29}$ H. Man S. Sastrawidjaja, op.cit, hlm. 187

${ }^{30}$ Anonim, 2016, Kedudukan Kreditor Separatis Dalam Mengeksekusi Barang Jaminan, Wawancara, 29 Agustus

${ }^{31}$ Anonim, 2016, Kedudukan Kreditor Separatis Dalam Mengeksekusi Barang Jaminan, Wawancara, 29 Agustus
} 


\section{PERLINDUNGAN HUKUM TERHADAP BANK YANG BERKEDUDUKAN SEBAGAI KREDITOR SEPARATIS DALAM PEMBAGIAN HARTA PAILIT}

Berkaitan dengan perlindungan hukum terhadap bank yang berkedudukan sebagai kreditor separatis, maka perlu diketahui mengenai beberapa faktor perlunya pengaturan dalam Undang-Undang No 37 Tahun 2004 tentang Kepailitan dan Penundaan Kewajiban Pembayaran Utang tentang Kepailitan dan Penundaan Kewajiban Pembayaran Utang yang telah disebutkan dalam penjelesan yakni:

a. Untuk menghindari perebutan harta debitor apabila dalam waktu yang sama ada beberapa kreditor yang menagih piutangnya dari debitor.

b. Untuk menghindari adanya kreditor pemegang hak jaminan kebendaan yang menuntut haknya dengan cara menjual barang milik debitor tanpa memerhatikan kepentingan debitor atau para kreditor lainnya.

c. Untuk menghindari adanya kecurangan-kecurangan yang dilakukan oleh salah seorang kreditor atau debitor sendiri. Misalnya, debitor berusaha untuk memberi keuntungan kepada seseorang atau beberapa orang kreditor tertentu sehingga kreditor lainnya dirugikan, atau adanya perbuatan curang dari debitor untuk melarikan semua harta kekayaannya dengan maksud untuk melepaskan tanggung jawabnya terhadap para kreditor.

\section{a. Hak kreditor Separatis Dalam Pembagian Harta Pailit}

Pasal 21 Undang-Undang No 37 Tahun 2004 tentang Kepailitan dan Penundaan Kewajiban Pembayaran Utang menyebutkan bahwa kepailitan meliputi seluruh kekayaan debitor pada saat putusan pernyataan pailit diucapkan serta segala sesuatu yang diperoleh selama kepailitan. Pasal 21 merupakan pelaksanaan dari Pasal 1131 KUHPerdata yang menunjukkan bahwa seluruh harta kekayaan debitor, baik yang bergerak maupun yang tidak bergerak, baik yang sudah ada maupun yang baru akan ada di kemudian hari, menjadi tanggungan (agunan) bagi seluruh utang debitor. ${ }^{32}$

\footnotetext{
${ }^{32}$ Sutan Remy Sjahdeini, op.cit, hlm. 180
} 
Jaminan diperlukan manakala debitor tidak mampu membayar utang-utangnya kepada kreditor dan kreditor dapat melaksanakan eksekusi terhadap barang jaminan tersebut untuk menutupi piutangnya. Pembagian harta pailit dilakukan setelah si pailit benar-benar dianggap tidak mampu membayar utangnya. ${ }^{33}$

Ketidakmampuan membayar utang ini terjadi apabila usulan perdamaian pada waktu rapat verifikasi tidak diterima kreditor. ${ }^{34}$ Bank $\mathrm{X}^{35}$ dan Bank $\mathrm{Y}^{36}$ dalam hal pembagian harta pailit lebih mengutamakan adanya eksekusi barang jaminan daripada adanya usaha perdamaian antara debitor dan kreditor.

Pembagian harta kepada kreditor dibayarkan secara bertingkat secara adil dan berurutan kepada kreditor separatis, kreditor preferen, biaya-biaya kepailitan dan kreditor konkuren. ${ }^{37}$ Kreditor akan memperoleh pembagian harta pailit sesuai dengan jumlah piutang atau sesuai dengan persentase yang wajar, dalam arti menurut besar kecilnya piutang yang dimiliki oleh masing-masing kreditor, dari harta pailit yang ada. ${ }^{38}$

\section{b. Perlindungan Hukum Terhadap Bank Yang Berkedudukan Sebagai Kreditor Separatis}

Memberikan kredit yang diberikan oleh Bank kepada nasabah dan dituangkan dalam bentuk perjanjian kredit secara tertulis. Perjanjian kredit merupakan perjanjian pendahuluan (pactum de contrahendo). ${ }^{39}$ Prinsip kehati-hatian juga diterapkan oleh Bank $\mathrm{X}$ pada saat memberikan kredit kepada debitor dengan memperhatikan tujuan penggunaan, jenis

\footnotetext{
${ }^{33}$ Tata Wijayanta, 2016,Undang-Undang dan Praktik Kepailitan, Gadjah Mada University Press, Yogyakarta, hlm. 197

${ }^{34}$ Ibid, hlm. 197

35 Anonim, 2016, Kedudukan Kreditor Separatis Dalam Mengeksekusi Barang Jaminan, Wawancara, Ambon, 29 Agustus

36 Anonim, 2016, Kedudukan Kreditor Separatis Dalam Mengeksekusi Barang Jaminan, Wawancara, Ambon, 19 September

${ }^{37}$ Marjan E. Pane, "Inventarisasi, Verifikasi, dan Pemberesan Harta Pailit", dalam Tata Wijayanta, 2016,Undang-Undang dan Praktik Kepailitan, Gadjah Mada University Press, Yogyakarta, hlm. 199

${ }^{38}$ Siti Anisah, 2008, Perlindungan Kepentingan Kreditor dan Debitor Dalam Hukum Kepailitan Di Indonesia, Total Media, Yogyakarta, hlm. 265

39 Sri Redjeki Slamet, "Perlindungan Hukum Dan Kedudukan Kreditor Separatis Dalam Hal Terjadi Kepailitan Terhadap Debitor”, forum ilmiah, volume 13, nomor 1, Januari, 2016, hlm. 54 (http://ejurnal.esaunggul.ac.id/index.php/Formil/article/viewFile/1394/1269)
} 
jaminan, jangka waktu dan jenis nasabah yang merupakan fasilitas kredit yang diberikan oleh Bank X.

Perlindungan yang diberikan oleh undang-undang kepailitan yang diperuntukkan kepada debitor dan kreditor dengan tujuan agar hak masing-masing pihak dilindungi dan tidak terjadi sengketa antara debitor dengan kreditor maupun kreditor dengan kreditor lainnya. Perlindungan yang dimaksudkan juga tidak memberikan dampak kerugian bagi kreditor maupun debitor. Kreditor yang dimaksudkan dalam tesis ini khususnya ialah bank, dikarenakan bank yang memberikan kredit kepada debitor. Berdasarkan Pasal 6 UndangUndang Nomor 10 Tahun 1998 tentang Perbankan menyebutkan salah satu usaha bank umum ialah memberikan kredit. Memberikan kredit yang diberikan oleh Bank kepada nasabah dan dituangkan dalam bentuk perjanjian kredit secara tertulis. Perjanjian kredit merupakan perjanjian pendahuluan (pactum de contrahendo). ${ }^{40}$ Perjanjian kredit yang telah dilaksanakan oleh debitor dan kreditor dilandaskan pada kepercayaan atau trust dan dalam hal ini bank berkedudukan sebagai kreditor yang telah memberikan kredit kepada debitor. Kepercayaan yang diberikan oleh bank sebagai kreditor kepada debitor hendaknya mendapatkan perlindungan yang memadai dan seimbang agar tidak terjadi kredit macet yang menyebabkan kerugian kepada bank, dan kepercayaan yang dimaksudkan diwujudkan dalam bentuk jaminan yang diberikan oleh debitor kepada kreditor. Bukan hanya kepercayaan yang menjadi dasar perjanjian kredit antara kreditor dan debitor, akan tetapi kehati-hatian juga harus menjadi pedoman dalam perjanjian kredit sehingga juga tidak menimbulkan adanya sengketa bahkan kerugian terhadap kreditor. Prinsip kehati-hatian diwujudkan dalam bentuk adanya jaminan diberikan kepada bank oleh debitor. Prinsip kehati-hatian juga diterapkan oleh Bank X pada saat memberikan kredit kepada debitor dengan memperhatikan tujuan penggunaan, jenis jaminan, jangka waktu dan jenis nasabah yang merupakan fasilitas kredit yang diberikan oleh Bank X.

40 Sri Redjeki Slamet, "Perlindungan Hukum Dan Kedudukan Kreditor Separatis Dalam Hal Terjadi Kepailitan Terhadap Debitor”, forum ilmiah, volume 13, nomor 1, Januari, 2016, hlm. 54 (http://ejurnal.esaunggul.ac.id/index.php/Formil/article/viewFile/1394/1269) 
Bank X menerapkan prinsip kehati-hatian dalam memberikan kredit kepada debitor, dan Bank $\mathrm{Z}$ juga menerapkan hal tersebut guna mencegah adanya kredit macet yang akan berdampak pada kerugian untuk Bank Z sendiri. Hasil wawancara dengan kepal bagian divisi legal Bank $\mathrm{Z}$ mengemukakan bahwa sangat selektif dalam memberikan kredit dengan cara debitor harus menunjukkan surat izin usaha, surat izin perdagangan, akta pendirian usaha dan laporan keuangan 6 bulan terakhir. ${ }^{41}$

Bank Z memiliki beberapa jenis-jenis kredit yang diberikan kepada nasabah yakni: ${ }^{42}$

1) Kredit modal kerja dengan jangka waktu 1-3 tahun

2) Kredit investasi

3) Kredit jangka panjang misalnya pembelian ruko

4) Kredit konsumtif KPR dengan jangka waktu maksimal 20 tahun

Bukan hanya bank $\mathrm{Z}$ yang selektif dalam memberikan kredit kepada nasabah, namun juga diterapkan oleh Bank X kepada para nasabah yang ingin mengajukan permohonan kredit. Syarat-syarat untuk memperoleh kredit dari Bank X ialah harus menyerahkan ktp, npwp, sertifikat, izin usaha dan mutasi rekening, sedangkan jumlah nasabah yang memperoleh kredit dari Bank X pada tahun 2014-2016 sebanyak 40 debitor dengan jumlah kredit yang diberikan ialah $50 \mathrm{M}^{43}$

Jaminan yang dimaksudkan sesuai dengan ketentuan Pasal 55 ayat (1) UndangUndang No 37 Tahun 2004 tentang Kepailitan dan Penundaan Kewajiban Pembayaran Utang yang menyebutkan antara lain jaminan gadai, jaminan fidusia, hak tanggungan, hipotek atau hak agunan atas kebendaan lainnnya, sehingga bank yang berkedudukan sebagai kreditor separatis dapat melaksanakan eksekusi haknya seolah-olah tidak terjadi

\footnotetext{
${ }^{41}$ Anonim, 2016, Kedudukan Kreditor Separatis Dalam Mengeksekusi Barang Jaminan, Wawancara, Ambon, 29 September

${ }^{42}$ Anonim, 2016, Kedudukan Kreditor Separatis Dalam Mengeksekusi Barang Jaminan, Wawancara, 29 September

${ }^{43}$ Anonim, 2016, Kedudukan Kreditor Separatis Dalam Mengeksekusi Barang Jaminan, Wawancara, 29 Agustus
} 
kepailitan. Jaminan yang telah disebutkan dalam Pasal 55 ayat (1) merupakan jenis jaminan kebendaan. Ciri-ciri dari jenis kebendaan yakni: ${ }^{44}$

a) Merupakan hak mutlak (absolut) atas suatu benda

b) Kreditor mempunyai hubungan langsung dengan benda-benda tertentu milik debitor

c) Dapat dipertahankan terhadap tuntutan oleh siapapun

d) Selalu mengikuti bendanya di tangan siapapun benda itu berada (droit de suite/zaaksquegevolg)

e) Mengandung asas prioritas yaitu hak kebendaan yang lebih dulu terjadi akan lebih diutamakan daripada terjadi kemudian (droit de preference)

f) Dapat diperalihkan seperti hipotek

g) Bersifat perjanjian tambahan (accesoir)

Jenis jaminan yang diatur oleh Bank X ialah secured loans yang merupakan pinjaman yang dijamin oleh uang tunai atau deposito atau SLBC yang diterbitkan oleh bank berperingkat, dan unsecured loans ialah pinjaman yang tidak di back-up secara hukum oleh jenis jaminan seperti pada secured loan. ${ }^{45}$ Jaminan yang pada umumnya juga diambil oleh kreditor dalam hal ini Bank $\mathrm{Y}^{46}$ ialah berupa Sertifikat Hak Milik, cash collateral, invoice dan BPKP. ${ }^{47}$ Jaminan yang pada umumnya diambil oleh Bank $\mathrm{Z}$ dibagi menjadi dua yakni jaminan utama dan jaminan tambahan. Jaminan utama misalnya tanah dan bangunan khususnya objek pembiayaan sebagai tempat usaha milik debitor, sedangkan jaminan

\footnotetext{
${ }^{44}$ Frieda Husni Hasbullah, 2009, Hukum Kebendaan Perdata Hak-Hak Yang memberi Jaminan, Indo Hill-Co, Jakarta, hlm. 18-19

${ }^{45}$ Anonim, 2016, Kedudukan Kreditor Separatis Dalam Mengeksekusi Barang Jaminan, Wawancara, 29 Agustus dicantumkan

46 Demi menjaga kerahasiaan, maka narasumber tidak menginginkan nama instansinya

47 Anonim, 2016, Kedudukan Kreditor Separatis Dalam Mengeksekusi Barang Jaminan, Wawancara, Ambon, 19 September
} 
tambahan misalnya kendaraan dan alat berat. ${ }^{48}$ Pada Bank $X$ jaminan yang pada umumnya diambil dari debitor ialah berupa sertifikat dan jaminan setoran tunai atau deposito. ${ }^{49}$

Bentuk perlindungan bagi kreditor sebagaimana diatur dalam Undang-Undang No 37 Tahun 2004 tentang Kepailitan dan Penundaan Kewajiban Pembayaran Utang antara lain: ${ }^{50}$

i.Memberikan fasilitas dan prosedur untuk mereka sehingga dapat memenuhi tagihan-tagihannya terhadap debitor

ii.Menjamin agar pembagian harta kekayaan debitor di antara para kreditor sesuai denganasas pari passu (membagi secara proporsional harta kekayaan debitor kepada para kreditor konkuren berdasarkan perimbangan besarnya tagihan masingmasing kreditor)

iii.Mencegah agar debitor tidak melakukan perbuatan-perbuatan yang dapat merugikan kepentingan para kreditor

iv.Menghukum pengurus yang karena kesalahannya mengakibatkan perusahaan mengalami keadaan keuangan yang buruk sehingga perusahaan mengalami insolvensi dan kemudian dinyatakan pailit oleh pengadilan

v.Memberikan kesempatan kepada debitor dan para kreditornya untuk berunding dan membuat kesepakatan mengenai restrukturisasi utang-utang debitor

Berdasarkan hasil wawancara dengan kepala bagian dvisi legal Bank $\mathrm{Z}$ yang mengemukakan bahwa permasalahan yang sering terjadi misalnya terdapat sertifikat ganda, objek jaminan yang di pesisiran pantai dan objek jaminan untuk lokasi kuburan. Ketiga contoh yang diungkapkan, menurut kepala bagian divisi legal Bank $\mathrm{Z}$ akan mempersulit keadaan untuk mengeksekusi jaminannya dikemudian hari apabila terjadi kredit macet, sehingga solusi atau jalan keluar untuk menangani permasalahan tersebut yakni pelaksanaan eksekusi atas barang-barang jaminan tersebut dengan menagih sebagiannya.

\footnotetext{
${ }^{48}$ Anonim, 2016, Kedudukan Kreditor Separatis Dalam Mengeksekusi Barang Jaminan, Wawancara, 29 September

${ }^{49}$ Anonim, 2016, Kedudukan Kreditor Separatis Dalam Mengeksekusi Barang Jaminan, Wawancara, 29 Agustus

${ }^{50}$ Sutan Remy Sjahdeini, op.cit, hlm. 45
} 


\section{PENUTUP}

1. Kedudukan Bank sebagai kreditor separatis memang telah diberikan oleh hukum untuk mengeksekusi barang jaminan milik debitor dalam hal terjadi kredit macet. Pasal 55 ayat (1) menyebutkan bahwa dengan tetap memperhatikan ketentuan sebagaimana dimaksud dalam Pasal 56, Pasal 57 dan Pasal 58 setiap kreditor pemegang gadai, jaminan fidusia, hak tanggungan, hipotek, atau hak agunan atas kebendaan lainnya, dapat mengeksekusi haknya seolah-olah tidak terjadi kepailitan. Akan tetapi hal tersebut dibatasi dengan adanya Pasal 56 ayat (10 yang mengatur mengenai masa penangguhan dengan tujuannya, yakni:

a. Untuk memperbesar kemungkinan tercapainya perdamaian, atau

b. Untuk memperbesar kemungkinan mengoptimalkan harta pailit, atau

c. Untuk memungkinkan kurator melaksanakan tugasnya secara optimal.

Permasalahan lainnya, Pasal 55 ayat (1) tidak konsisten dengan pengaturan pada Pasal 59 ayat (1) yang mengatur pada mengenai pelaksanaan haknya kreditor dalam jangka waktu dua bulan. Hal tersebut memberikan adanya batasan-batasan yang tidak konsisten dengan Pasal 55 ayat (1) dalam hal kreditor separatis dapat melaksanakan haknya yang tidak dipengaruhi oleh putusan pernyataan pailit terhadap debitor.

2. Perlindungan yang diberikan oleh hukum ialah diaturnya mengenai pelaksanaan dari hak eksekusi oleh kreditor separatis. Tujuan dengan adanya Pasal 55, Pasal 56 dan Pasal 59 ialah agar kreditor separatis dapat melaksanakan haknya, akan tetapi ketiga pasal tersebut dinilai tidak konsisten sehingga bank juga membuat peraturan internal untuk mencegah terjadi kerugian apabila kredit macet. Tindakan yang perlu dilakukan oleh bank apabila terjadi kredit macet ialah melakukan eksekusi terhadap barang jaminan milik debitor pailit, dan eksekusi yang dilakukan bank dikenal dengan nama parate executie. Ada dua cara yang dilakukan yakni, lelang dan penjualan di bawah tangan. Lelang dilaksanakan bukan hanya untuk mendapatkan peminat saja, namun juga untuk mendapatkan harga tinggi agar dapat menutupi utang debitor. Apabila lelang tidak berhasil, maka akan dilaksanakan penjualan dibawah tangan. 


\section{DAFTAR PUSTAKA}

Anisah, Siti, 2008, Perlindungan Kepentingan Kreditor dan Debitor Dalam Hukum Kepailitan Di Indonesia, Total Media, Yogyakarta.

Fuady, Munir, 2005, Hukum Pailit dalam teori dan praktek, PT. Citra Aditya Bakti, Bandung.

Hasbullah, Frieda Husni, 2009, Hukum Kebendaan Perdata Hak-Hak Yang Memberi Jaminan, Indo Hill-Co, Jakarta.

Hermasyah, 2008, Hukum Perbankan Nasional Indonesia, Prenada Media Group.

Manan, Bagir, 2001, Mengenal Perpu Kepailitan, Penyelesaian Utang-Piutang, Melalui Pailit atau Penundaan Kewajiban Pembayaran Utang, Alumni, Bandung.

Marzuki, Peter Mahmud, 2005, Penelitian Hukum, Prenada Media Group, Jakarta.

Mulyadi, Kartini, 2005, Kreditor Preferen dan Kreditor Separatis dalam Kepailitan, Pusat Pengkajian Hukum, Jakarta.

Nating, Imran, 2004, Peranan dan Tanggung Jawab Kurator Dalam Pengurusan dan Pemberesan Harta Pailit, PT. RajaGrafindo Persada, Jakarta.

Puspa, Yan Pramadya, 2009, Kamus Hukum Edisi Lengkap Bahasa Belanda, Indonesia, Inggris, Aneka Imu, Semarang.

Sastrawidjaja, H. Man S, 2010, Hukum Kepailitan dan Penundaan Kewajiban Pembayaran Utang, PT. Alumni, Bandung.

Shubban, M. Hadi, 2008, Hukum Kepailitan Prinsip, Norma, dan praktik di Peradilan, Kencana Prenadamedia Group, Jakarta.

Sianturi, Purnama Tioria,2013, Perlindungan Hukum Terhadap Pembeli Barang Jaminan Tidak Bergerak Melalui Lelang, Mandar Maju, Bandung.

Sjahdeini, Sutan Remy, 2009, Hukum Kepailitan; Memahami Undang-Undang Nomor 37 Tahun 2004 Tentang Kepailitan, PT. Pustaka Utama Grafiti, Jakarta.

Suci, Ivida Dewi Amrih, 2009, Hak Kreditor Separatis Dalam Mengeksekusi Benda Jaminan Debitor Pailit, Laksbang Pressindo, Yogyakarta.

Sutedi, Adrian, 2009, Hukum Kepailitan, Ghalia Indonesia, Bogor. 
Wijayanta, Tata, 2016, Undang-Undang dan Praktik Kepailitan, Gadjah Mada University Press, Yogyakarta.

Yani, Ahmad dan Gunawan Widjaja, 2004, Seri Hukum Bisnis Kepailitan, PT. RajaGrafindo Persada, Jakarta.

Sri Redjeki Slamet, Perlindungan Hukum Dan Kedudukan Kreditor Separatis Dalam Hal Terjadi Kepailitan Terhadap Debitor, Forum Ilmiah, Volume 13, Nomor 1, Januari, 2016, hlm. 52-59

Anonim, 2016, Kedudukan Kreditor Separatis Dalam Mengeksekusi Barang Jaminan, Wawancara, Ambon, 29 Agustus.

Anonim, 2016, Kedudukan Kreditor Separatis Dalam Mengeksekusi Barang Jaminan, Wawancara, Ambon, 19 September.

Anonim, 2016, Kedudukan Kreditor Separatis Dalam Mengeksekusi Barang Jaminan, Wawancara, Ambon, 29 September. 